\title{
Chia-Ping Kan, Les pactes entre la noblesse et les bas- fonds dans quelques romans de Balzac
}

\section{Marco Stupazzoni}

\section{(2) OpenEdition}

1 Journals

\section{Edizione digitale}

URL: http://journals.openedition.org/studifrancesi/6023

DOI: $10.4000 /$ studifrancesi.6023

ISSN: 2421-5856

\section{Editore}

Rosenberg \& Sellier

\section{Edizione cartacea}

Data di pubblicazione: 1 mai 2011

Paginazione: 189-190

ISSN: 0039-2944

\section{Notizia bibliografica digitale}

Marco Stupazzoni, «Chia-Ping Kan, Les pactes entre la noblesse et les bas-fonds dans quelques romans de Balzac», Studi Francesi [Online], 163 (LV | I) | 2011, online dal 30 novembre 2015, consultato il 07 janvier 2021. URL: http://journals.openedition.org/studifrancesi/6023 ; DOI: https://doi.org/10.4000/ studifrancesi.6023

Questo documento è stato generato automaticamente il 7 janvier 2021.

\section{(c) (1)}

Studi Francesi è distribuita con Licenza Creative Commons Attribuzione - Non commerciale - Non opere derivate 4.0 Internazionale. 


\title{
Chia-Ping Kan, Les pactes entre la noblesse et les bas-fonds dans quelques romans de Balzac
}

\author{
Marco Stupazzoni
}

\section{NOTIZIA}

CHIA-PING KAN, Les pactes entre la noblesse et les bas-fonds dans quelques romans de Balzac, «Revue d'Histoire Littéraire de la France», 110e année, n 2, avril-juin 2010,

pp. 295-312.

1 Attraverso lo studio di tre momenti fondamentali del sistema narrativo balzachiano interno alla Comédie humaine: 1830-1831 (Gobseck e La Peau de chagrin); 1834 (Le Père Goriot); 1838-1847 (Illusions perdues e Splendeurs et misères des courtisanes), viene posta in primo piano, nelle riflessioni dell'A., la complessa, ambigua e drammatica rete di rapporti tra alcune figure-simbolo della nuova e giovane aristocrazia parigina divenute vittime inette e solitarie della propria epoca - e i titanici modelli di male assoluto (Vautrin, su tutti) i quali, essendo perfettamente inseriti e dominanti rispetto alle dinamiche della società del proprio tempo, assumono il ruolo di loro maestri e guide nell'intricato e minaccioso labirinto della società parigina. La relazione che lega indissolubilmente questi personaggi si fonda sul concetto di "patto" (diabolico, senza alcun dubbio) all'interno di un contesto socio-economico e politico in cui domina incontrastata la logica del "Pouvoir" e del denaro. Un contesto dove la nobiltà, per sfuggire al proprio inevitabile annientamento o per evitare di essere ridotta a semplice elemento decorativo in questo quadro generale, si vede costretta a sottoscrivere, senza troppi compromessi, un patto, un'alleanza eternamente viva con le forze del Male. 